\title{
CONCEPTUALISING A FIDUCIARY DUTY ON AUDITORS
}

\author{
Loganathan Krishnan ${ }^{1}$
}

\begin{abstract}
Auditors are a key feature of a company. They perform an important role as they report on a company's financial affairs. The report is presented at the company's general meeting for the benefit of shareholders of the company who will consequently evaluate the performance of the company's management. Furthermore, the report is lodged at Companies Commission of Malaysia which can be accessed by various parties who wish to rely on the report. Hence, auditors hold a public office and auditors' report is considered as a public document. In light of this, this paper explores the possibility of attaching a fiduciary duty on auditors. This paper then proceeds to examine the manner courts deal with this concept. This is important since the concept is used extensively in relation to directors, company secretaries, receivers and liquidators. Nonetheless, in relation to auditors, it is relatively a new concept. This paper will also examine the challenges faced by auditors with this new concept. In 2007, essentially a new provision was incorporated in the Companies Act 1965 imposing a duty of good faith on auditors and to be absolved from any civil or criminal liability. Hence, this paper examines the implications of imposing such a duty on auditors. Interviews were carried out with auditors, academics, professional bodies, relevant bodies and regulatory bodies to derive in-depth views on the subject matter. Be that as it may, the duty to act in good faith is imposed on most professionals and due to the fact that auditors are professionals, the legislature imposed a similar duty on auditors. The fiduciary duty imposed on auditors will bring about more rights not only to shareholders but other parties too. Thus, this will enhance the duties and obligation of auditors in the current corporate atmosphere. This is essential as there are an increasing number of financial scandals which involve auditors. Thus, imposition of a fiduciary duty further improves the reputation of the audit profession.
\end{abstract}

\footnotetext{
Department of International Business, Faculty of Accountancy and Management, University of Tunku Abdul Rahman, Bandar Sungai Long Campus, Lot PT 21144, Jalan Sungai Long, Bandar Sungai Long, Kajang, 43000, Selangor. Tel: 0390194722 Ext: 131, Fax: 03 90197062, loganathan@utar.edu.my
} 


\section{Introduction}

This paper examines whether auditors owe a fiduciary duty to a company. The discussion then evaluates whether there is a fiduciary relationship between a company and its auditors. The paper then investigates whether such fiduciary relationship is imposed based on the manner in the provisions of the Companies Act 1965 (Companies Act), Banking and Financial Institutions Act 1989 (BAFIA) and Capital Market and Services Act 2007 (CMSA). The discussion also includes the results of interviews carried out with auditors, academics, regulators, professional bodies and relevant bodies to obtain their views on the concept of fiduciary relationship between a company and its auditors.

\section{Should Auditors Owe a Fiduciary Duty?}

\section{a) The Views of the Courts in the United Kingdom}

In Henderson v Merret, ${ }^{2}$ the English court pointed out that auditors owe a fiduciary duty to the company. This is due to the nature of their duties and obligations. Nonetheless, the court pointed out that the fiduciary duty is parallel to contractual duty. This is questionable because fiduciary duty is not akin to contractual duty. Fiduciary duty demands a wider scope of auditors' duties and obligations compared to contractual duty. Furthermore, fiduciary duty expects a higher standard and degree of care on auditors to carry out their duties and obligations. Moreover, fiduciary duty covers a wider category of persons and bodies to whom the duty is owed. Fundamentally, fiduciary duty applies in situations where one party reposes trust and confidence on the other party.

Moreover, a contractual duty requires parties to a contract to perform their duties and obligations based on the terms and conditions of the contract. The parties to the contract need to be concerned of only themselves and no one else. Hence, a contractual duty requires a narrower scope of obligations and performance from the parties. This is to be contrasted with fiduciary duty whereby auditors need to consider the interests of other parties who may rely on the report.

[1995] 2 AC 145 
Hence, it is submitted that the decision of Henderson v Merret ${ }^{3}$ is wrong in law to treat fiduciary duty as synonymous to contractual duty. However, the court in Henderson v Merret ${ }^{4}$ is correct in holding that auditors are under a fiduciary duty which is owed to the company.

In Sayers v Clarke-Walker (a firm) ${ }^{5}$ the plaintiff decided to buy shares in a private company from the main shareholders. The defendant acted for the company and the main shareholders. Both the plaintiff and the main shareholders wanted the defendant to act for the plaintiff in relation to purchase of shares. After the purchase of shares, the plaintiff suffered a loss since the purchase was not structured in a manner which benefits him in relation to taxation matters. The English Court of Appeal found that the defendants are in breach of their fiduciary duty. The court stated that if the auditors are engaged by two different parties who may be in conflict, they are required to give competent advice as they are in a fiduciary position. However, there are only two cases where the English courts found that auditors are under a fiduciary duty which is owed to the company. Nevertheless, there are views of the courts that auditors are under a fiduciary duty which is owed to the company.

\section{b) The Views of the Court in Malaysia}

As to the position in Malaysia, reference should be made to the case of Onestop Software Solutions (M) Sdn Bhd v Masteritec Sdn Bhd $\& \mathrm{Ors}^{6}$ where Ramly Ali $\mathrm{J}$ made it clear that auditors are under a fiduciary duty not to disclose any matters which are confidential. This is because they are professionals. It should be noted that this is the first time the Malaysian court stated that auditors are under a fiduciary duty.

Although the Malaysian court found that auditors owe a fiduciary duty to the company, the legislations which govern auditors must be scrutinized to determine whether auditors owe a fiduciary duty.

\footnotetext{
[1995] 2 AC 145

4 [1995] 2 AC 145

5 [2002] EWCA Civ 910

6 [2009] 8 MLJ 528
} 


\section{c) The Position under the Companies Act 1965}

The duties and obligations imposed by the Companies Act, BAFIA and CMSA outline auditors' duties and obligation. Nonetheless, the legislations do not stipulate how the duties and obligations should be carried out i.e. that the auditors must be honest. It is at this juncture that the concept of fiduciary duty is important as it requires auditors to carry out their duties and obligations honestly. This is important especially in relation to auditors' duty to disclose the true state of company affairs to the extent that in some cases disclosures must be made to the Registrar, Bank Negara Malaysia BNM) and the Securities Commission (SC) as required by S. 174(8) and (8A) of the Companies Act, S. 40(13) and (15) of BAFIA and S. 128 of the CMSA. It should be noted that these provisions do not prescribe that auditors owe a fiduciary duty to a company. Nevertheless, the succeeding section shows a scrutiny of the provisions.

S. 174(8) of the Companies Act provides that in carrying out auditing duties, if auditors discover that there is a breach of the Companies Act and it has not or will not be adequately dealt with by the report or the directors of the company, they are bound to report to the Registrar. This is a watchdog function of the auditors ${ }^{7}$ given that auditors are required to report to the regulators. It also shows that the auditors owe a fiduciary duty since they are required to report to the regulators. Although auditors are appointed by the company and required to report to the members of the company, by virtue of S. 174(8) of the Companies Act, they are also required to report to regulators. Auditors must also consider persons other than members of the company. There is a wider category of persons, auditors should consider. Furthermore, this provision shows that audit is not merely an internal matter as it involves the regulators. Although, a contractual duty will not require auditors to do so, a fiduciary duty requires auditors to do so.

However, it is a qualified duty as auditors are under such a duty only if the auditors discover a breach of the Companies Act or the auditors' report will not adequately cover the matter. ${ }^{8}$ Nonetheless,

\footnotetext{
Hanrahan, P, Ramsay, I, Stapledon, G, Aiman Nariman and Aishah Bidin, Commercial Applications of Company Law in Malaysia,(Singapore: $\mathrm{CCH}$, 2002), at 361 .

8 Cheah, Foo Seong, Guide to Company Law and Secretarial Practice, Malaysia, (Singapore: CCH Asia Pte Ltd, 2006).
} 
it is a watchdog function as the provision requires auditors to review the steps taken by the Board of Directors in order to address the breach of the Companies Act. However, the predicament is the standard expected of auditors on this matter. This is because it is unclear whether it is based on what the auditors believe or whether the auditors could have reasonably discovered it. The provision reads "...if an auditor...is satisfied..." Thus, the provision suggests that it is based on what the auditor believes since it is worded subjectively. Notably, the duty to report to the Registrar does not arise if the auditors do not consider that there is a breach or non-observance of the Companies Act. The provision does not prescribe any duty since the duty is determined by the auditors themselves. The provision should incorporate a duty based on objective standard whereby it should read "....where an auditor...ought to have known that there has been a breach ..." In that situation, an objective standard is imposed whereby the standard is based on what reasonable and competent auditors would have known in the given circumstances. In that case, a fiduciary duty can be imposed on auditors based on what reasonable auditors would have done.

Another issue which must be addressed is that the provision is criminal in nature because the penalty which can be imposed is a two years imprisonment or a fine of RM 30,000 or both. Thus, the issue is whether auditors should be satisfied on the balance of probabilities or beyond reasonable doubt. Essentially, the degree of satisfaction should increase with the gravity of the imputation the auditors are making. ${ }^{9}$ Therefore it is submitted that the standard should be based on beyond reasonable doubt.

Another provision which requires scrutiny is S. 174(8A) of the Companies $\mathrm{Act}^{10}$ which provides that auditors of a public company are under a duty to report to the Registrar if the auditor is of the opinion that a serious offence involving fraud or dishonesty is being or has been committed against the company or the Companies Act by officers of the company. It is to be noted that auditors' duty involves regulator as they are required to report to the regulator. Thus, it can be argued that auditors under a fiduciary duty as they are required

Pound, G, “Auditors' Obligations”, Australian Accountant 64(1) (1994): 50.

10 This provision has been inserted by Companies (Amendment) Act 2007 (Act A1299) in July 2007. 
to act in the interests of the regulators as they must discharge their duties responsibly. The spirit of this provision is similar to S. 174(8) of the Companies Act.

A concern is that the duty is only imposed on auditors of a public company or a company which is controlled by a public company. Furthermore, S. 174(8C)(a) of the Companies Act provides that a company is considered as being controlled by a public company if the public company has not less than $15 \%$ of voting shares in that company. There is no valid legal justification to require auditors to report on fraud or dishonesty only on companies where the public companies have $15 \%$ of voting shares. The public company may choose to hold $14 \%$ of voting shares to avoid this provision. Furthermore, it does not mean that there is no fraud or dishonesty in private company. Auditors of public company should be treated the same as auditors of private company.

The provision may be justified on the basis that in public companies, the public invested their money in the company and thus regulators are required to protect their interests. However, it was reported in 2010 that there is a trend in Malaysia whereby public companies convert to private companies in recent years. ${ }^{11}$ In fact, the shareholders of such companies are concerned of such a trend as such privatizations affect the stock market ${ }^{12}$ as it wipes out RM46.3 billion.

Moreover, the difficulty with this provision is the manner the auditors will form their opinion. The provision is worded subjectively i.e. "... if the auditor is of the opinion..." It is difficult to apply the provision in cases where the auditors are not of the opinion that there is any fraud or dishonesty. The provision should be drafted to read "the auditor is of the professional opinion that there is no fraud or dishonesty committed in the course of performance of their duties." In such a case, auditors are under a duty to detect fraud.

Additionally, the provision does not impose a duty on the auditors to detect fraud. It only states that $[\mathrm{IF}]^{13}$ the auditor is of the opinion that there has been a fraud or dishonesty, he is under a duty to report

11 Risen Jayaseelan, "Concern on Privatization", The Star, August 5, 2010, B1.

12 New Straits Times, "Privatisation Wipes Out RM46.3b From Stock Market", June 20, 2007, 37.

13 Emphasis added. 
to the Registrar. Hence, the emphasis is placed on his duty to report fraud or dishonesty but not the duty to detect fraud. The provision should be amended to read that auditors are required to detect fraud or dishonesty. Notably, the duty of auditors to report to the Registrar in cases where there is fraud or dishonesty is inadequate as the Registrar does not represent the interests of the various parties who have an interest in the matter. Additionally, the Companies Act does not provide what the next course of action of the Registrar is with regards to the report. The provision does not provide that the Registrar will make the report public through any form of media for the knowledge of the various parties. Thus, the provision falls short of taking into account the interests of other parties except the regulators' interests.

It should be noted that the terms fraud and dishonesty are not specifically defined in the Companies Act. Nevertheless, S. 174(8C) (b) of the Companies Act provides that a serious offence involving fraud or dishonesty means an offence that is punishable by imprisonment for a term that is not less than two years or the value of the assets derived or any loss suffered by the company, member or debenture-holder exceeds RM 250,000 and includes offences under S. 364, S. 364A, S. 366 and S. 368 of the Companies Act. Essentially, the offence involving fraud or dishonesty must be an offence as provided for under the Companies Act. Furthermore the fact that the provision uses the term "...includes..." shows that $\mathrm{S}$. 174(8A) of "the Companies Act is not confined to S. 364, S. 364A, S. 366 and S. 368 of the Companies Act. Thus, the concept of true and fair view no longer acts as a yardstick for auditors to check the accounts of a company since there is a duty to report on fraud and dishonesty reposed on auditors. Observably, the duty to report fraud and dishonesty is of a higher duty compared to the duty to report on the company's accounts. This is because the duty to report fraud and dishonesty is result oriented whereas the duty to report on the company's accounts is process oriented. Thus, this again proves to show that auditors are under a fiduciary duty.

Notably, the duty to detect fraud and dishonesty is only imposed on auditors in 2007 by virtue of the amendment to the Companies Act, whereas the duty was imposed on auditors in the banking 
sector in $1989 .{ }^{14}$ It took eighteen years for the legislature that the duty to report fraud or dishonesty should also be imposed on auditors in other sectors although such a duty is essential. Hence, corporate accounting does not do violence to the truth occasionally, and trivially, but comprehensively, systematically and universally, annually and perennially". ${ }^{15}$ Fundamentally fraud can also distort a company's accounts.

It should be pointed out that the element of good faith is required for promoter ${ }^{16}$ director, ${ }^{17}$ company secretary, ${ }^{18}$ receiver ${ }^{19}$ and liquidator ${ }^{20}$ through statutory provisions and case law. There are no statutory provisions which impose a duty of good faith on auditors from the time the Companies Act was enacted in 1965. Nonetheless, the legislature intended the concept to apply to auditors as can be seen in S. 174A(2A) of the Companies Act which was done in 2007. Similar words can also be seen in S. 128(2) and S. 320(2) of the CMSA which was enacted in 2007. This means that auditors are required to act honestly when they prepare auditors' report. This means that auditors are under a fiduciary duty which owed to the company. Hence, it is proposed that the duty of good faith is also included in BAFIA so that the approach of the legislature is uniform towards all auditors in all sectors. Otherwise, auditors in the nonbanking sector may claim that they are treated unfairly by the laws as they are under a fiduciary unlike auditors in the banking sectors.

In addition to the cases decided by the English courts and the Malaysian courts, it can be argued that auditors are under a fiduciary duty since auditors must avoid any conflict of interest. This can be seen in S. 9 of the Companies Act which stipulates the category of persons who are disqualified from being appointed as auditors. The provision is drafted to ensure that officers and employees of a company are not eligible to be appointed as auditors. Furthermore, S. 174(1) of the Companies Act requires auditors to report to the

14 This will be discussed in the succeeding section.

15 Chambers, R J, "Accounting and Corporate Morality: The Ethical Cringe", 1 Australian Journal of Corporate Law No 1 (1991): 9 \& 16.

16 Erlanger v New Sombrero Phosphate Co (1878) 3 App Cas 1218

17 Re Smith \& Fawcett Ltd [1942] Ch 304

18 Re Morvah Consols Tin Mining Co., McKay's Case (1875) 2 Ch D 1

19 China and South Sea Bank Ltd v Tan Soon Gin [1990] 1 AC 536

20 Re R Gertzenstein Ltd [1957] Ch 115. 
company at the general meeting. This means that auditors are required to report to the members of the company. The interests of the members are based on collective interests. Hence, auditors must not act for their own interests, the interests of the Board of Directors or the interests of the majority shareholders at the expense of their duty to audit.

If auditors offer non-audit services to a company, this amounts to a case of conflict of interest. This is because auditors earn a higher income through non-audit services compared to audit fees. In 2001, Arthur Andersen earned US\$55 million for non-audit services. ${ }^{21}$ As far as the banking sector is concerned, $70 \%$ of the fees that banks pay to their auditors are for non-audit services. ${ }^{22}$ In 1993, 31\% of the auditing industry's fees came from non-audit services. ${ }^{23}$ On average, for every dollar of audit fees, the companies paid \$2.69 for non-audit services. ${ }^{24}$ A study conducted in Australia showed that 27 out 58 companies of the top 100 Australian companies admit that the auditors they engaged also offer non-audit services. ${ }^{25}$ In fact, it reached a point where audit and non-audit services are indistinguishable. ${ }^{26}$ It was reported that in the year 2000, the 'Big Four' audit firms $\mathrm{s}^{27}$ earn $50 \%$ of their income from management and consultancy which was only $13 \%$ in $1981 .{ }^{28}$ There is also evidence that revenue from other services has increased. ${ }^{29}$ The Ethics Standards Board which is part of the UK accountancy regulator

${ }^{21}$ Brown, R E, "Enron/Andersen: Crisis in U.S. Accounting and Lessons for Government", Public Budgeting and Finance 25(3) (2005): 20.

22 Economist, "A Murky Sort of Pond Life", 7 June 2002, 70.

23 Byrnes, N, Brady, D, Lavelle, L and Palmeri, C, "Accounting Crisis", Business Week, 2002.

24 Bailey, K, Bylinski, J and Shields, M, "Effects of Audit Report Wording Changes on the Perceived Message Journal of Accounting Research 21(2) (1983): 355-370.

25 Watts, T, "Non-Audit Fees Survey: A Review of the Non-Audit Services Performed by the Auditors of the ASX Top 100 from 1992-2002, Institutional Analysis, Melbourne, November 2002, 19.

26 Jeppesen, K K, "Reinventing Auditing, Redefining Consulting and Independence", The European Accounting Review No 7 (1998): 517-539.

27 Price WaterhouseCoopers, KPMG, Ernst \& Young and Deloitte

28 Securities and Exchanges Commission of the United States of America, Proposed Rule: Revision of the SEC Commission's Auditor Independence Requirements, (Washington D.C: SEC, June 2000).

29 Palmrose, Z V, "Audit Fees and Auditor Size: Further Evidence", Journal of Accounting Research 24(1) (1986): 97-110. 
is of the opinion that auditors should not provide audit and nonaudit services to the same client. ${ }^{30}$ The management of the company prefers to engage the auditors for non-audit services because of the comfortable personal relationship with the auditors. ${ }^{31}$ Auditors usually offer non-audit services to the company which they audit. If auditors are strict in carrying out their duties and obligations, there is a possibility that they lose their contracts for non-audit services. Additionally, auditors shall not divulge any confidential information to any person except as required by the Companies Act, BAFIA and CMSA.

Thus, the provisions of the Companies Act do point towards the argument that auditors are under a fiduciary duty. Furthermore, considering the importance of auditors in the current corporate atmosphere and the impact if auditors' report turns out to be untrue, auditors owe a fiduciary duty.

The succeeding section will examine whether a fiduciary duty can be argued on the basis of the provisions of BAFIA.

\section{d) The Position under the Banking and Financial Institutions Act 1989}

S. 40(13) of the BAFIA provides that BNM may at any time require an auditor to submit such additional information as BNM may specify; enlarge or extend the scope of his audit as BNM may specify; carry out any specific examination or establish any procedure in any particular case or submit a report on any of the matter above. BNM may specify the time within which the above is required. The provision shows that auditors do not only owe a duty to the financial institution but BNM too. This is because BNM has a right to involve itself in the financial institution's affairs. It also shows that in the event the duties and obligations under the Companies Act are insufficient, the duties and obligations under BAFIA could be extended by BNM. Furthermore, the applicable

30 Parker, A, “Accountants Attack Plan to Restrict Auditors' Role", Financial Times, October 12, 2002, 2.

31 Joseph, C V, Hermanson, R H and McGrath, N T, "Audit Quality Attributes: The Perceptions of Audit Partners, Preparers and Financial Statement Users", Auditing: A Journal of Practice and Theory 11(1) (1992): 1-15. 
accounting standards are not exhaustive as BNM may impose some other procedure to be adopted by the auditors. This provision shows that auditors are under a fiduciary duty as they also owe a duty to BNM which is not a party to the contract.

Moreover, S. 40(15)(a) of the BAFIA provides that auditors of banks and financial institutions are under a duty to report to BNM if there is any contravention of BAFIA or any offence which relates to dishonesty or fraud under any other law. ${ }^{32}$ This means that the application of S. 40(15) of the BAFIA is wider than S. 174(8A) of the Companies Act since the latter is confined to fraud and dishonesty where as the former includes any offence under any other law.

Nonetheless, the concern is whether BNM represents the interests of the stakeholders since auditors are required to report to BNM. ${ }^{33}$ Additionally, the provision is unclear as to what the next course of action on the part of BNM is after receiving the report.

S. 40(15)(b) of the BAFIA provides that an auditor shall report to BNM if losses have been incurred by the financial institution which reduce its capital funds to an extent that it is no longer able to comply with the specifications of BNM. By virtue of S. 40(15)(c), the auditor shall report to BNM if there is any irregularity which jeopardizes the interests of depositors or creditors of the financial institution. Finally under S. 40(15)(d), he must report if he is unable to confirm that the claims of depositors or creditors are covered by the assets of the financial institution. The provisions show that the auditors must consider the interests of the creditors. Such a requirement is not found in the Companies Act although there are creditors involved non-financial companies.

32 Reference should be made to the Indian legal position as can be seen in the case of Deputy Secretary v. S.N. Das Gupta (1955) 25 Com Cas 413 whereby an auditor of a banking company failed to verify the cash balance claimed by the management and the actual cash in hand turned out to be much less than was shown in the books. Hence, the auditor failed to detect fraud although he was required to do so by virtue of the banking legislation in India.

33 Loganathan Krishnan, "The Role of Auditors in the Banking Sector", paper presented at the Applied International Business Conference, Universiti Malaysia Sabah, November $6^{\text {th }}-8^{\text {th }}, 2008$. 
Thus, it can be seen that auditors have to consider the interests of regulators, creditors, investors and depositors. This shows that there is a wider category of persons auditors must consider. Auditors cannot only consider the interests of the company it audits. Thus, it s submitted that based on the provisions of BAFIA, auditors are under a fiduciary duty.

\section{e) The Position under the Capital Market and Services Act 2007}

The CMSA took effect on 1st December 2007. The Securities Industry Act 1983 and the Futures Industry Act 1993 which formerly governed the regulations for securities and futures industry in Malaysia were merged and formed part of the new CMSA. The intention is to have a single Act which is effective and market-oriented. Apart from this two Acts, a few provisions in the Securities Commission Act 1993 were also consolidated into the CMSA. CMSA is significant in terms of its new provisions to strengthen investor protection. ${ }^{34}$

In view of that, focus is centered on the provisions which govern auditors. The duties of auditors are provided in S. 128(1) of the CMSA. The provision reads that if an auditor becomes aware of any matter which in his opinion may constitute a breach of this Act; of any irregularity that may have a material effect on the company's accounts including any irregularity that jeopardizes the funds or property of the clients of the company; that losses have been incurred by the company that it is unable to meet the minimum financial requirements as prescribed by the Act; he is unable to confirm that the claims of clients or creditors of the company are covered by the assets of the company; that an offence in connection with the business of the relevant person has been committed; or in the case of public listed company there has been a contravention of the rules of a stock exchange, the auditor shall immediately report the matter to the stock exchange and SC.

34 Asmah Laili Yeon, "The Capital Markets and Services Act 2007: Is it a Reformation in the Law of Securities and Futures Industry in Malaysia?" paper presented at the International Conference on Corporate Law: Contemporary Roles and Challenges, Universitas Airlangga Surabaya, June $1^{\text {st }}-3^{\text {rd }}, 2009$. 
The provision shows that it is the auditors' duty to whistle-blow ${ }^{35}$ in the secondary market. ${ }^{36}$ The provision uses a very general word i.e. offence as opposed to fraud or dishonesty in S. 174(8A) of the Companies Act and S. 40(15) BAFIA. This means that the duty of auditors to whistle-blow is not only confined to fraud and dishonesty but to any offence under any law. Hence, the duties and obligations of auditors under CMSA are very wide. It can be observed that the intention of the legislature is to impose higher standards on auditors from the existence of the Companies Act in 1965 to the introduction of CMSA in 2007.

S. 128(3) of the CMSA provides that the SC may at any time require the auditor to submit such additional information; extend the scope of his audit; carry out any specific examination or establish any procedure in any particular case; to submit a report on any of the matter referred above; or submit an interim report on any of the matters above. A similar provision is found in S. 320(3) of the CMSA. The provisions were invoked in respect of Comsa Farms Bhd whereby the SC asked the auditors, Moores Rowland to do extra verification work and provide more information on the company's draft audited accounts for the year 2005. ${ }^{37}$ The auditors have to carry out the additional duties. It can be seen that this provision is similar to S. 40 of BAFIA.

Another provision which requires attention is S. 320 of the CMSA which only applies to public listed companies. The provision provides that if an auditor is of the professional opinion that there has been a breach or non-performance of any requirement or provision of the securities laws, a breach of any of the rules of the stock exchange or any matter which may adversely affect to a material extent the financial position of the listed corporation, the auditor shall immediately submit a written report on the matter in the case

\footnotetext{
35 Loganathan Krishnan, "A Legal Scrutiny on the Role of Auditors in WhistleBlowing", paper presented at the Tuanku Ja'afar Law Conference - International Conference on Corporate Governance and Corporate Responsibility, Kuala Lumpur, October 19th - $20^{\text {th }}, 2010$.

36 Shanti Geoffrey, “The CMSA - Ensuring Gatekeepers' Accountability”, paper presented at the Corporate Law and Governance Seminar, Company Law Development in United Kingdom and the Financial Crisis - Implications For Malaysia, Kuala Lumpur, $21^{\text {st }}$ July 2010.

37 Business Times, "SC Asks Comsa Auditor For More Info", November 25, 2005.
} 
of a breach or non-performance of any requirement or provision of the securities laws, to the Commission; in the case of a breach or non-performance of any of the rules of a stock exchange, to the relevant stock exchange and the Commission; or in any other case which adversely affects to a material extent the financial position of the listed corporation, to the relevant stock exchange and the Commission. This is also a duty to whistle-blow by the auditors. ${ }^{38}$

It should be noted that the duties are akin to those duties imposed under S. 128 of the CMSA and BAFIA except that the regulators are different. This means that auditors of a financial institution or a public company regardless of whether it is listed are bound by the duties as specified under BAFIA and CMSA respectively. This is in addition to those duties imposed under the Companies Act. Nonetheless, upon close scrutiny of S. 320 of the CMSA, the provision uses the term "...professional opinion..." Such a provision is not found in the Companies Act, BAFIA or the other provisions of the CMSA regarding auditors' duties. It can be seen that the legislature is aware on the importance of auditor's opinion. The legislature recognizes the fact that auditors form professional opinion. At the same time auditors will have to bear in mind that their opinion is important for the various parties and the duty should not be taken lightly. Thus, it can be argued that auditors owe a fiduciary duty to the company based on the provisions of CMSA.

\section{f) The Position under Contracts Act 1950}

In addition to audit, auditors may offer non-audit services to a company. In cases where the Board of Directors or the management of the company is pressured by auditors to award the contract to offer non-audit services to the auditors, the issue is whether there is free consent by the company.

This is because S. 10(1) of the Contracts Act 1950 (CA) provides that all agreements are contracts if they are made by free consent. S. 13 of the CA 1950 provides that two or more persons are said to

38 Hazlina Shaik Noor Alam, "Whistleblowing and Corporate Governance: Accidental Allies or Lifetime Partners?" paper presented at the International Conference on Corporate Law: Contemporary Roles and Challenges, Universitas AirLangga Surabaya, June $1^{\text {st }}-3^{\text {rd }}, 2009$. 
consent when they agree upon the same thing in the same sense. S. 14(b) of the CA 1950 provides that consent is said to be free when it is not caused by undue influence. S. 16(1) of the CA 1950 reads that a contract is said to be induced by undue influence where the relations subsisting between the parties are such that one of the parties is in a position to dominate the will of the other and uses that position to dominate the will of the other and uses that position to obtain an unfair advantage over the other. S. 16(2) of the CA 1950 provides that a person is deemed to be in a position to dominate the will of another where he holds a real or apparent authority over the other, or where he stands in a fiduciary relation to the other.

Arguably, auditors are in a position to dominate the will of the company since they are in a fiduciary relationship with the company. They may use their position to influence the Board of Directors or the management of the company to award the contract to offer nonaudit services to them. The unfair advantage obtained by them is that the company does not have a choice to offer non-audit services to another person, firm or company.

Therefore, auditors are in a position to dominate the will of the company. According to S. 16(3) of the CA, where a person who is in a position to dominate the will of another, enters into a contract with him, and the transaction appears, on the face of it or on the evidence adduced, to be unconscionable, the burden of proving that the contract was not induced by undue influence shall lie upon the person in a position to dominate the will of the other. Therefore, the burden is on the auditors to prove that there is no domination of the will of the company.

It should be pointed out that there are no cases on this point where undue influence was raised against the auditors with regards to the offer of non-audit services. However, the point is arguable since there are elements of domination, influence and unfair advantage. In the event, undue influence can be established the contract for nonaudit services is voidable. A voidable contract is interpreted in S. 2(i) of the CA 1950 as an agreement which is enforceable by law at the option of one or more of the parties thereto, but not at the option of the other or others. Thus, the option is available to the company against the auditors. 
S. 20 of the CA 1950 provides that when consent to an agreement is caused by undue influence, the agreement is a contract voidable at the option of the party whose consent was so caused. Any such contract may be set aside absolutely or, if the party who was entitled to avoid it has received any benefit there under, upon such terms and conditions as the court may seem just. Thus, if the auditors provided the non-audit services, the company is not able to rescind the contract but will have to pay for the services. If the auditors have not provided the non-audit services, the company is able to rescind the contract.

In relation to the issue of non-audit services, it is difficult for the company to prove there is undue influence by the auditors, in order to rescind the contract. Thus, it is proposed that auditors should not be allowed to offer non-audit services to the company.

\section{Research Methodology}

The research methodology used in this study is library research and also survey by interviews. Interviews refer to a form of direct communication between the interviewer and the respondent in a face-to-face meeting. ${ }^{39}$ This is a flexible method and has a twoway method of communication whereby the interviewer can ask questions during the interview. ${ }^{40}$ Additionally, there is instant feedback which can give room to more questions, detail information and visual demonstration. The interviewer also has a control over the discussion and is able to cater to any unique situations if they arise. The type of interview conducted is a respondent interview type. The interviewer directs the interview and the interviewee responds to the questions of the researcher. ${ }^{41}$ The interviews conducted are in-depth in order to find out what is the current situation. ${ }^{42}$

The interviews were conducted on auditors, academics, regulators, professional bodies and interested bodies. The categories of respondents are as follows:

39 Kahn, R and Canneell, C, The Dynamics of Interviewing, (New York and Chichester: Wiley, 1957)

40 Saunders, M, Lewis, P and Thornhill, A, Research Methods for Business Students, (Harlow: Prentice Hall, 2007).

${ }_{41}$ Easterby-Smith, M, Thorpe, R and Lowe, A, Management Research: An Introduction, $2^{\text {nd }}$ ed., (London: Sage, 2002).

42 Robson, C, Real World Research, 2 ${ }^{\text {nd }}$ ed., (Oxford: Blackwell, 2002). 
Table 1

Persons and bodies interviewed

\begin{tabular}{cll}
\hline NO & PERSONS/BODIES INTERVIEWED & \multicolumn{1}{c}{ LOCATION } \\
\hline 1 & AUDITORS $^{1}$ & FEDERAL TERRITORY \\
& & SABAH \\
& & SARAWAK \\
& & PENANG \\
2 & ACADEMICS & KEDAH \\
& & UKM \\
3 & CCM & UIA \\
4 & MIA & KUALA LUMPUR \\
5 & MSWG & KUALA LUMPUR \\
\hline
\end{tabular}

Results of Interviews ${ }^{43}$

\section{a) Auditors' Views}

The auditors responded that initially, the relationship between auditors and the company is contractual. However, the provisions of the Companies Act, BAFIA and the CMSA imposed various duties on auditors. Thus, auditors cannot be concerned of the company only. Hence, it is found that the relationship between auditors and a company is more than just mere contractual.

The auditors also said that in fact it can be seen that since the involvement of CCM, SC, BNM and Bursa, the responsibilities of auditors are extended further. This cannot be avoided since the duties of auditors have to be enhanced. Furthermore, the fact that auditors' report is lodged with CCM shows that it is a public document. Thus, auditors cannot claim that their relationship is only with the company. This is especially in cases where it is a listed company. As far as a company is concerned, it only deals with auditors but as far as auditors are concerned, they have to bear in mind that there are others who have an interest in the outcome of auditors' report. However, if it is a small company, the responsibilities of auditors are to the shareholders of the company which is to prepare the auditors' report.

43 For the purposes of confidentiality, the names of the respondents cannot be revealed in this paper. 
The auditors continued by arguing that the traditional relationship between the company and the auditors has changed. This is because in some situations there will be familiarity and friendship with the client. To a small extent this will affect the independence and objectivity of the auditors. Thus, auditors must ensure that the risk is insignificant and should not at any point of time neglect their duties just because of familiarity and friendship.

Thus, the relationship between auditors and a company is not merely contractual but more than contractual. However, the relationship should not be too close. Auditors must remain independent otherwise it will be a threat to the profession. There must be a gap between auditors and a company. However, in terms of fraud and dishonesty, it can be said that the relationship is more than contractual.

Since, auditors are knowledgeable and are trusted by various persons and bodies, it can be argued that auditors are under a fiduciary duty. Furthermore, there is a certain extent of personal element in the audit process. This is because auditors must be distinguished from financial analysts. Auditors are considered as trustees and are not supposed to take any sides. Moreover, auditors must be independent. However, what is more important is to interpret the term fiduciary properly. But considering the amount of responsibilities attached to auditors in recent years, it can be argued that auditors are under a fiduciary duty.

Some auditors found that it is not a valid argument to state that auditors are under a fiduciary duty. This is because one must look at the scope of engagement. It cannot be determined that auditors are under a fiduciary duty merely because various parties place reliance on auditors.

\section{b) Academics' Views}

The relationship between a company and its auditors is more than merely contractual. First, it has to be established as to whom the fiduciary duty is owed. It has to be naturally the company since it is the company which appointed the auditors. Thus, it can be argued that auditors are under a fiduciary duty. 


\section{c) Regulators' Views}

The representative of the CCM stated that the relationship between auditors and a company is more than just mere contractual as proven in some case laws i.e. 1136 Tenants v Max Rothenberg and Company, ${ }^{44}$ where although auditors were never engaged to conduct an audit for 1136 Tenants Corporation, the auditors were found liable for failing to detect an embezzlement scheme conducted by one of the client's managers. Thus, the role and duties expected of auditors placed them as a fiduciary as they are acting as watchdogs to protect the interest of members of the company and to inform the regulators on any non-compliance issues or fraud by company's officers.

\section{d) Minority Shareholder Watchdog Group's Views}

The representative of the MSWG stated that auditors are appointed by shareholders. That is what the law requires and this is complied with at the annual general meetings of the company. In practice, it is common knowledge that auditors are appointed by the directors. In principle, it is also open to shareholders to reject the directors' choice of auditors and to recommend their own appointment. However, in the real world, they always accept the directors' recommendation. This attitude undeniably damages auditors' independence. Irresponsible directors with utmost self-interest would tend to promote a rosy picture of the management's performance and their conduct would have the most influence and power in the appointment and remuneration of auditors.

Given the increased role and duties of auditors, directors should not be allowed any significant voice in the appointment of a company's auditors. In this way, it is possible to avoid "the more than just mere contractual relationship between auditors and a company" as pointed out here. An audit does not involve the preparation and presentation of the financial information which is management's responsibility. It involves the independent examination and reporting on that information. Once auditors accept their appointment as auditors, a legal relationship is established with their client. There is clearly a role for independent, non-executive directors in audit committee

$44 \quad 319$ N.Y.S.2d 1007, 1009 (1971) 
to play their role and be effective as corporate watchdogs. It is also the auditors' responsibility to ensure that their relationship with the board of directors is a statutory function. Their legal obligation is to report that directors present a true and fair view of the accounts.

Given the increased role and duties expected of auditors it is appropriate to place auditors as a fiduciary. It is, however, recognized that the role of auditors is a statutory requirement in the public interest. Although auditors are in a position of trust, they perform a statutory duty and a legal obligation, different from directors who have a fiduciary duty to act in the best interests of the company. Directors owe a fiduciary duty to their companies. Fiduciary duty is a duty owed by a director to his company in the form of two principles. He must not make secret profit and he must not allow any conflict to arise between his interest and his duty to the company. In any event, if a director made a secret profit and nobody knew about it, no one could raise an objection to it. However, auditors cannot be in such a position as a director. A director is expected to act in good faith. It is incumbent for the Board of Directors to act collectively and individually when they discharge their duties. The business judgment rule in the law is what the courts ought to recognise and to refrain from second guessing whether or not the directors have been deemed to make decisions in good faith or otherwise.

\section{e) Malaysian Institute of Accountants’ Views}

The representative of the MIA claimed that the relationship between auditors and a company is more than merely contractual since auditors will now have to consider the interests of all stakeholders as they rely on auditors' report. The representative is of the view that auditors are under a fiduciary duty considering the scope of their duties and obligations. Moreover, there is reliance by all the stakeholders on auditors' report. The representative opined that it is definitely a non-audit services is a conflict of interest. In fact, in Europe, if a person does audit, he is not allowed to do non-audit. Thus, the same position should be adopted in Malaysia to further minimize the number of possible scandals that involve auditors. 


\section{Conclusion}

It is a trite fact that the relationship between a company and its auditors is contractual. Nevertheless, the relationship is not merely contractual as auditors hold a public office. Furthermore, auditors' report does not only belong to a company since it is lodged with $\mathrm{CCM}$ and thus it is a public document. The document is accessed by various parties who may rely on the report since auditors are external and independent person. Furthermore, the parties who wish to rely on the report do not have rights and powers similar to auditors to examine a company's financial documents. Moreover, there is little significance to establish that there is a contractual relationship between a company and its auditors since most of the time it is not the company which suffered a loss and wishes to bring an action against the auditors. It is the third parties who are at a loss. Observably, the views of the English and the Malaysian courts do show that auditors are under a fiduciary duty which is owed to the company. Furthermore, the provisions of the Companies Act, BAFIA and the CMSA do show that auditors are under a fiduciary duty and the trend can be seen especially with the incorporation of the duty of good faith on auditors.

\section{(Footnotes)}

1 A total number of 22 auditors were interviewed. 